\title{
How Perception use of e-Filling Technology Enhance Knowledge of Indonesian Disability Taxpayers and Impact Tax Compliance
}

\author{
Yana Hendayana $^{1}$, Harry Mulyadi ${ }^{2}$, Fitriani Reyta ${ }^{3}$, Radhi Abdul Halim ${ }^{4}$ \\ ${ }^{1,4}$ Universitas Widyatama Bandung, Indonesia \\ ${ }^{2}$ Universitas Pendidikan Indonesia \\ ${ }^{3}$ Universitas Bisnis dan Informatika, Bandung, Indonesia \\ fitrianireyta@gmail.com
}

\section{Abstract}

Taxes are a source of state revenue used to finance government spending and development. One of the taxes that the government imposes on its people is income tax including income from dissability. Referring to the large number of persons with disabilities in Indonesia, indeed there should be no difference in the treatment of the fulfillment of rights between normal people and disabilities. Philosophically and constitutionally, based on Pancasila and the 1945 Constitution, every citizen has a chance which is equally good in terms of work, accessing public facilities, get a decent life and livelihood, and so on. This is emphasized for the fulfillment of the rights of disabilities. Innovation of online accessibility for public services is one solution for disabilities taxpayers in Indonesia. SPT reporting via djponline one of them. The presence of efilling intended for makes disability taxpayers easier to participate in carrying out their tax obligations as citizens, but there is contrast in the field often taxpayers with special needs have not felt much benefit from the existence of this technology, for this reason the researcher decides to examine whether e-filling can affect the increase in taxpayer knowledge among disabilities, 85 samples taken from disabilities SMes in Bandung West Java, The data is processed using the partial least square method and using a quantitative approach, result shown as much as $58.47 \%$ the existence of e-Filling enchance the tax knowledge of persons with disabilities and non significance impact the tax compliance, they argue that all it needs is advanced technology on a disability-friendly website.
Keywords

disability, taxpayers, e-filling, compliance; knowledge

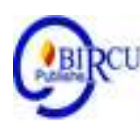

\section{Introduction}

Duty as far as the Tax Collecting Agency can be separated into two kinds, to be specific state assessment and neighborhood charge. There are five kinds of expenses collected by the state. One of the duties that the legislature forces on its kin are an annual expense. Kesit (2004) state that annual tax (PPh) is an assessment that is forced on pay got or gotten by people or people and elements for one charge year. Annual duty comprises of $\mathrm{PPh} 21$, PPh 22, PPh 23, PPh 24, PPh 25 and PPh 26. From tax.go.id cleary said expense gathering will diminish the salary of somebody who makes good on regulatory expenses, yet really the assessment is a necessary tool that originates from the pay of somebody whose year surpasses taxable income (PTKP). The people group is obliged to make good on regulatory obligations and report their yearly expense form to the closest charge office 
or an organization that has been enrolled as a corporate citizen is required to report the measure of PPh 21 of its workers. Duty incomes are really come back to the open in a roundabout way. Through state foundation advancements, all assessment accumulation will in a roundabout way come back to the network as an advantage felt by the individuals who make good on regulatory expenses or not. This is expressed in Law No.28 of 2007, that: "Duties are required commitments to the state owed by people or substances that are coercively dependent on the Act, with no immediate remuneration and are utilized for state purposes for the measure of - incredible thriving of the individuals. "The legislature is making upgrades to assess guidelines in Indonesia, so charge income can expand each year in accordance with populace development in Indonesia. One of them is personal duty $(\mathrm{PPh})$ 21. Annual duty 21 is an expense on a pay as compensation, compensation, honorarium, benefits, and different installments of whatever name got or acquired by a local individual Taxpayer regarding work or position, administrations, and exercises. Changes that happen are changes in Non-Taxable Income (PTKP).

According to Siti (2011: 6) Income Tax (PPh) is a tax that is imposed on tax subjects on income received or obtained in a tax year. Income Tax is a type of subjective tax whose tax obligations are attached to the relevant Tax Subject, meaning that the tax obligation is intended not to be delegated to other Tax Subjects. Therefore, to provide legal certainty, determining when to start and end subjective tax obligations is important (forum.kompas.com). Income Tax subject is anything that has the potential to earn income and is subject to income tax. If the Tax Subject has fulfilled the tax obligations objectively or subjectively, it is called a Taxpayer. Article 1 of Law No. 16 of 2000 concerning KUP states that taxpayers are individuals or entities that according to the provisions of tax legislation are determined to carry out tax obligations, including certain tax collectors and tax-cutters (Siti, 2011: 6). Tax subjects who receive or obtain income, in Law No. 36 of 2008 concerning Income Tax (PPh) called Taxpayers. According to Siti (2011: 6), the object of taxation is anything (goods, services, activities, or circumstances) that are subject to tax. The object of income tax is income, which is an additional economic capability received or obtained by taxpayers, both from Indonesia and from outside Indonesia.

When viewed from the side of taxpayers, Mardiasmo (1997: 104) says the reason people are less enthusiastic about paying taxes (less tax compliance) is because of a lack of knowledge about taxes. Theoretically, to foster a positive attitude about something that must originate from the existence of knowledge about it. Taxpayer compliance can be further grown if tax management is also disciplined, and the tax apparatus works honestly. Tax administration has a very important role in supporting the success of a tax policy that has been taken. The purpose of tax administration according to Rosdiana (2003: 10), is to encourage a voluntary tax compliance. Voluntary tax compliance can be maintained well if there is an effective tax administration. Thus, tax administration is considered effective if it can increase voluntary 'tax compliance. An effective administration not only determines the level of voluntary compliance of taxpayers but can also be an important factor for the success of a tax collection policy carried out by a country.

Taxpayers in the term of disabled person in Indonesia still faced many inequality of information rights as stated by Setyaningsih and Gutama (2016) that disabled in the eyes of the community when this is still underestimated as a party to be pitied. For families who have family members with disabilities sometimes make them a disgrace covered family it's existence. Disabled in Indonesia must face the "culture disgrace ", in a culture of disgrace the physical appearance that always looks be the main spotlight than attitudes held within. Disability limitations must be dealing with rigid systems that are applies to the community, the system division of labor and system interaction. The company refused because there 
are employees with disabilities the limitations it has will be affect its performance, with In other words, the performance of employees with disabilities slow and not on target. Disable causes poverty through several processes exclusions that occur within daily life like disabled participation tends to be very minimal good in the social realm and politics. Most of the definable has a tendency the "exclusive" in the middle community life in the sense alienating himself in the process community interaction. Certainly very influential on her development because this tendency makes disabled people with minimal access to information and communication. Lack of information and communication certainly matter to social and economic conditions from the disabled themselves, where they are can't open social networks (social networking) very important especially to access world of work.

Anticipating the development of information and technology and also the equalization of disability rights, the Directorate's Office The Tax General has implemented an electronic archive. Where is this electronic archive, is a renewal in the taxation system carried out by the Directorate General of Taxes to facilitate, improve and optimize services to Taxpayer (Wahyuni, 2015). The Directorate General of Taxes seeks to fulfill aspirations Taxpayers by simplifying the procedure for reporting tax returns (Annual Tax Return and Annual Tax Return) which are expected to later have an impact on increasing tax revenue in Indonesia. Tax revenue is the dominant revenue from all state revenues. The use of eFiling can be influenced by the taxpayer's perception of the usefulness of the system eFiling itself.

Perception is a view that is preceded by sensing of objects (objects, humans, ideas, symptoms and events) through the five senses so that it immediately gives meaning and value to an object by highlighting the nature typical of an object and the results of perception can be in the form of responses or judgments that are different from individuals (Ismail et al, 2020). The definition of perception is the process of one's understanding of something object (Lie, 2013). According to Wahyuni (2015), Perception of Use is a measure of where the use of technology is believed to bring benefits to every individual who uses it. If taxpayers feel that with e-Filing Taxpayers can simplify, simplify and improve the performance of tax reporting become better and able to increase the level of productivity, quality, effectiveness, and save time in the tax reporting process as well as more practical and efficient so bring benefits in carrying out its tax obligations, the Taxpayer will tend to use e-Filing in fulfilling their tax obligations. The use of e-Filing can also be influenced by the ease of use of the system the e-Filing.

The definition of perceived ease is how individual interpret that learning and using the system is a thing that is easy (Desmayanti, 2012). Ease of use can be felt if the taxpayer can operate e-Filing as needed in its tax reporting, very flexible to use, information and eFiling display easy to read and understand, and Taxpayers feel that e-Filing is not a complicated system to use. If the ease of use is felt by the taxpayer, it is most likely Taxpayers tend to use e-Filing to fulfill obligations the taxation. Devina and Waluyo (2016) stated that the speed of accessing the e-Filing system can also affect taxpayers in using e-Filing. In using eFiling Taxpayers do not need to come to the Tax Service Office, Taxpayers only need access e-Filing website that can be done anytime and anywhere so time what is needed by the Taxpayer to report his tax obligations becomes briefer, and if confirmation from the Directorate General of Taxes (ex. Proof of Revenue Electronic) which is directly sent by email to the Taxpayer quickly, then the Mandatory Taxes will tend to use e-Filing to fulfill obligations the taxation.

Widyadinata and Toly (2014) say the main purpose of e-Filing is to improve services to the public by facilitating electronic SPT reporting through internet media to taxpayers. This will help cut costs and time needed by the taxpayer to prepare, process, and report the 
tax return to the tax office correctly and on time. New problems arise from that purpose, not all of the disability taxpayers understand internet usage and website facilities, moreover if the website itself is not disability-friendly, they need a companion to fill eFilling, with the cost of developing a system that is high cost and the determination the purpose of equalizing the disability rights that have not been tested, that problem becomes background of this study was made to test whether e-filling technology is able to increase knowledge of taxpayers with special needs in Indonesia.

\section{Review of Literature}

\subsection{Taxes}

Understanding taxes and the views of experts in the field provide various definitions of different taxes, but basically, these definitions have the same purpose. For more details and to understand the meaning of what is meant by tax, several tax definitions are put forward as follows: Taxes are one source of government funds for development, both the central and regional governments. Tax collection can be forced because it is carried out according to the law (Siregar et al, 2019). Tax is a public contribution to the State treasury (transfer of private sector wealth to the law) based on the Act (can be forced) with no reciprocal services (tegen prestatie) which can be directly demonstrated and used to finance public expenditure (publieke uitgaven) (Marpaung, 2020). According to Soemitro quoted Mardiasmo (2011: 1) and Siti Official (2011: 6) that: "Tax is a public contribution to the state treasury based on the law (which can be forced) by not getting lead services (contra) which can be directly addressed and used to pay general expenditure ". Law No.28 of 2007 concerning the Third Amendment to Law No.6 of 1983 concerning General Requirements and Tax Procedures (KUP) that: "Tax is the contribution of taxpayers to the state-owned by individuals or entities that are forcing based on the law by not getting a direct reward and used for the purposes of the state for the greatest prosperity of the people ". According to Waluyo (2013: 11) Income Tax Article 21 is income tax that is imposed on income in the form of salaries, wages, honorariums, benefits, and other payments of any name in connection with work, services, or activities carried out by a domestic Individual Taxpayer. Furthermore, the legal basis for the imposition of Income Tax Article 21 is Article 21 of the Income Tax Act; Regulation of the Director-General of Tax Number Per 31 / Pj / 2009 concerning Technical Guidelines for Procedures for Withholding, Depositing and Reporting Article 21 Income Tax and/or Article 26 Income Tax relating to the work, services, and activities of private individuals has been amended by Regulation of the Director-General of Taxes Number 57 / Acting / 2009 October 12, 2009.

\section{2 e-Filing}

e-Filing is a method of submitting an SPT or submitting an Extension Notice Annual SPT electronically conducted on-line in real-time through the website Directorate General of Taxes www.pajak.go.id or Application Service Provider Service Provider (ASP) (www.kemenkeu.go.id). e-Filing serves the delivery of 2 types of tax returns, namely: (www.kemenkeu.go.id)

1) Annual Personal Income Tax Return WP Form $1770 \mathrm{~S}$

Used for WP Individuals whose source of income is derived from one or more employers and have other income that is not from business activities and/or free work.

2) Annual Personal Income Tax Return WP Form 1770 SS 
Used for individuals whose source of income is from an employer (as an employee) and the gross income does not exceed Rp. 60,000,000 per a year and no other income except income from bank interest and cooperative interest.

\subsection{Dissability}

Reyta et all (2019) state as indicated by Law Number 19 Year 2011 concerning Ratification of the Rights of Persons with Disabilities, people with inabilities, to be specific individuals who have physical, mental, scholarly or tangible restrictions for a significant stretch of time who connect with nature and the frames of mind of their kin can experience obstructions that make it hard to take an interest completely and successful dependent on fairness of rights. 2 Law Number 4 of 1997 concerning Persons with Disabilities in the central matters of show point 1 (first) opening gives seeing, to be specific: Every individual who has physical and/or mental issue, which can meddle or establish hindrances and connections for him to do appropriately, comprising of, physically crippled individuals; handicapped individuals mental; physically and rationally incapacitated. There are a few kinds of individuals with uncommon needs/incapacities.

Setyaningsih and Gutama (2016) the term "disabled" was changed with the word "diffable" (different ability). Substitute for this term intended to give finer as well as more meaning humanize the needy special. With disabilities terms, the public was invited to reconstructing values the previous one looked at the condition of the defect or not normal as deficiency or inability to be understanding of the diffable as humans with physical conditions different.

\subsection{Knowledge of Taxpayers and Tax Compliance}

Knowledge of a taxpayers are information about expenses or taxes can be seen from the learning in regards to how to do assess commitments, who is forced, what is forced, the amount it is, and how to ascertain it. Supramono and Damayanti (2005: 5) states that the citizen must know the measure of duty owed when to pay, and the cutoff time for installment. The information communicated by a portion of these individuals is fundamentally the learning of expense identified with the information of material duty law and formal assessment law. Material expense law contains standards which among others clarify the conditions, activities, lawful occasions that are saddled (charge object), who is burdened (subject to assess), how much duty is collected (rates), and everything about emerging and overlooking assessment obligations. A model is the Land and Building Tax Act. Formal assessment law contains structures/strategies for bringing material expense law into the real world (how to execute material duty law). This law incorporates, among others, the systems (methods) assurance of an assessment obligation, the lawful rights to regulate citizens (conditions, activities, and occasions that bring about an assessment obligation), citizens' commitments (keeping books and records), and citizen's privileges (documenting complaints and offers). This was uncovered by Mardiasmo (2001: 5). There are two types of compliance, formal compliance and material compliance: (1) Formal compliance is a condition where taxpayers fulfill tax obligations formally in accordance with the provisions in tax laws, (2) Material compliance is a condition where the taxpayer substantively fulfills all tax material provisions, according to the contents and life Constitution. If related to Land and Building Tax (PBB), compliance can mean that taxpayers report data relating to ownership of land and buildings in Tax Objects (SPOP), and compliance in paying UN owed. Salamun added, indicators of the level of fulfillment tax liability consists of tax ratio and the level of filling and submission of Notification of Debt (SPT) in a timely manner. 


\subsection{Research Framework}

Herdjati's research (1996) concluded that the compliance of taxpayers in paying land and building tax was influenced by the level of education and knowledge of taxpayers concerned. The same thing was expressed by Misbah (1997) through his research which concluded that the taxpayer's knowledge factor has a relatively close relationship with the level of tax compliance in carrying out its Land and Building Tax obligations in Surabaya. Nazir (2010) also supported this statement that the degree of tax knowledge and the effectiveness of the tax administration system, both partially and simultaneously, has (have) positive and significant effect to the tax compliance. Nurmantu (1998: 37) added that the ease of tax administration includes the provision to not carry out part or all of the tax administration activities. Administrative activities are defined as activities carried out by taxpayers in the context of fulfilling tax obligations as required in applicable tax regulations. Simplification of tax administration means a process that alleviates the burden of tax administration, from a complicated and complicated taxation procedure to a simple one which consequently will provide tax administration convenience for taxpayers. Sriartati's research (2000) revealed that the taxation system adopted by an area greatly affected the level of public awareness in paying land and building taxes.

Based on the literature review, the research framework is arranged in the following figure:

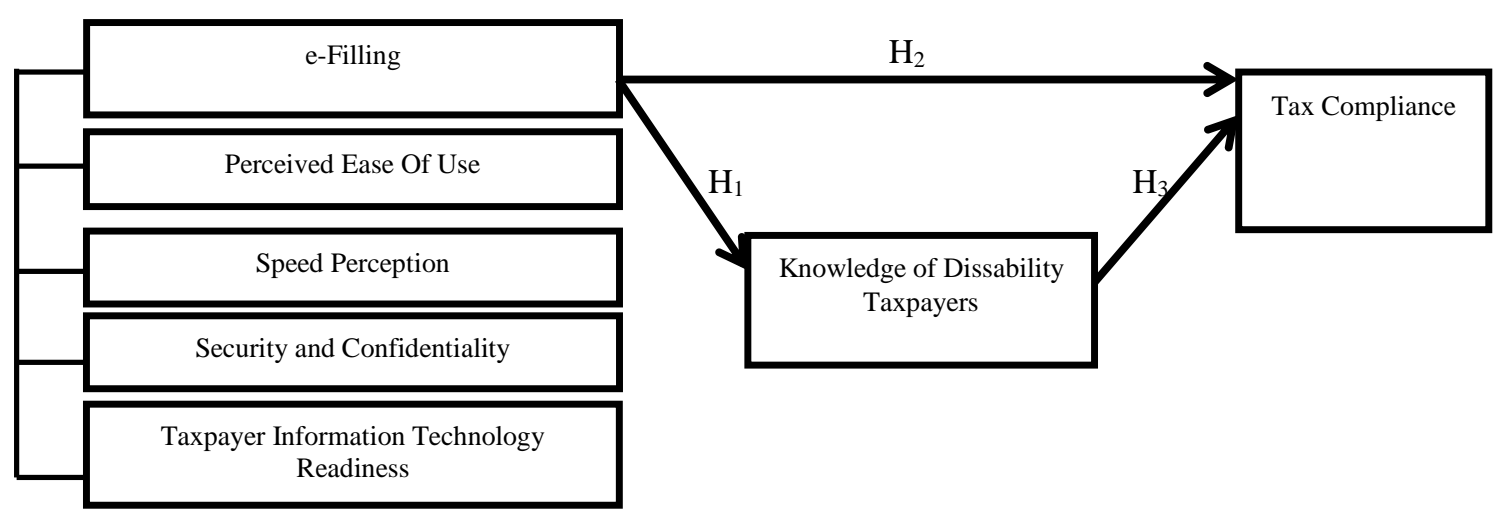

Figure 1. Research Framework

Based on the framework chart above, a hypothesis can be drawn as follows:

$\mathrm{H}_{1}$ : There is an enchacement of using a e-Filling to Knowledge of Dissability Taxpayers.

$\mathrm{H}_{2}$ : There is a direct impact of perceived ease of use e-filling on of Dissability Tax Compliance $\mathrm{H}_{3}$ : There is an impact of using e filling to Tax Compliance through Knowledge of Dissability Taxpayers

\section{Research Methods}

The sort of research led by scientists is engaging examination. This investigation has a place with a solitary cross-sectional plan, in particular, research directed once during one period (Malhotra, 2010: 108). Information accumulation is finished by-poll study strategies to respondents who are domiciled in the Bandung territory and who registered as SMEs Dissability. The information investigation system in this examination utilizes halfway least square. Partial Least Square (PLS) is a relapse family-based strategy for the creation and advancement of models and strategies for sociologies with prescient situated methodologies. Information will be handled utilizing the measurable strategy utilizing XLSTAT programming help. The populace for this examination is all disability taxpayers 
all through Indonesia. As per Sugiyono (2013: 120) clarifies that: "Examples are a piece of the number of attributes controlled by the populace". In this examination, the examples were registered as a member of disability community and gain earning as SMEs and were domiciled in the city of Bandung. In deciding the number of test individuals the scientists verified that the normal populace of disability taxpayers for as far back as 1 (one) year was 550 person, and afterward, the information was prepared with Slovin equation as following:

Where:

$\mathrm{n} \quad=$ number of samples

$\mathrm{N} \quad=$ number of population $=550$

$\mathrm{d}^{2} \quad=$ precision (set at $10 \%$ and $90 \%$ confidence level)

Based on the formula obtained the number of samples as follows:

$$
\begin{aligned}
& \mathrm{n}=\frac{550}{[550(0,1) 2+1]} \\
& \mathrm{n}=84,61 \\
& \mathrm{n}=85 \text { (rounded up) }
\end{aligned}
$$

In this investigation, the testing method utilized is non-likelihood inspecting with coincidental examining systems. Information used to construct this examination are essential information and optional information. Essential information is information that originates from specialists, gathered by scientists to manage an exploration issue confronted acquired from the consequences of perceptions and polls. While, the auxiliary information is prior information, which has been gathered to take care of research issues, optional information in this examination is the investigation of databases of disability taxpayers in Bandung City, West Java itself that have been using e-Filling.

\section{Results and Discussion}

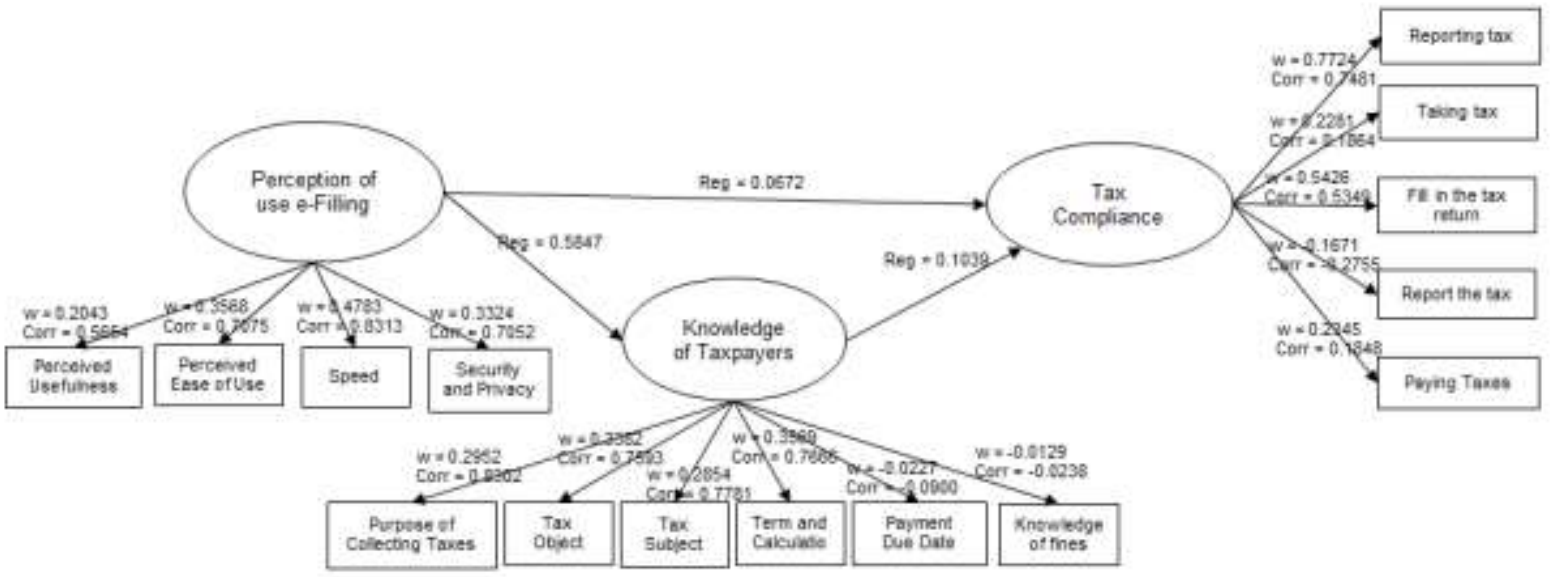

Figure 2. Result of Hypothesis Testing 
Tabel 1. Outer and Inner Model Evaluation

\begin{tabular}{|c|c|c|c|c|c|c|}
\hline \multirow[b]{3}{*}{ Variabel } & \multirow[b]{3}{*}{ Dimension } & \multicolumn{4}{|c|}{ Outer Measurement } & \multirow{3}{*}{$\begin{array}{c}\text { Inner } \\
\text { Measurement } \\
\text { Goodness Of } \\
\text { Fit Model }\end{array}$} \\
\hline & & \multicolumn{2}{|c|}{ Validity } & \multicolumn{2}{|c|}{ Reliability } & \\
\hline & & $\begin{array}{c}\text { Cross } \\
\text { Loading }\end{array}$ & $\begin{array}{c}\text { Mean } \\
\text { Communalit } \\
\text { ies (AVE) }\end{array}$ & $\begin{array}{c}\text { Cronbach' } \\
\text { alpha }\end{array}$ & $\begin{array}{l}\text { D.G. rho } \\
\text { (PCA) }\end{array}$ & \\
\hline \multirow{4}{*}{$\begin{array}{l}\text { Perception of } \\
\text { Using e- } \\
\text { Filling }\end{array}$} & $\begin{array}{l}\text { Perceived } \\
\text { Usefullness }\end{array}$ & 0.5654 & 0.5022 & 0.7768 & 0.8051 & \multirow{15}{*}{0.9401} \\
\hline & $\begin{array}{l}\text { Perceived Ease of } \\
\text { Use }\end{array}$ & 0.7075 & & & & \\
\hline & Speed & 0.8313 & & & & \\
\hline & Security and Privacy & 0.7052 & & & & \\
\hline \multirow{6}{*}{$\begin{array}{l}\text { Knowledge of } \\
\text { Taxes }\end{array}$} & $\begin{array}{l}\text { Purpose of } \\
\text { Colecting Taxes }\end{array}$ & 0.8302 & 0.5113 & 0.9618 & 0.7596 & \\
\hline & Tax Object & 0.7593 & & & & \\
\hline & Tax Subject & 0.7781 & & & & \\
\hline & Term and Calculation & 0.7666 & & & & \\
\hline & Payment Due Date & 0.5900 & & & & \\
\hline & Knowledge of Fines & 0.5238 & & & & \\
\hline \multirow{5}{*}{$\begin{array}{l}\text { Compliance } \\
\text { of Tax }\end{array}$} & Reporting Tax & 0.7481 & & & & \\
\hline & Taking Tax & 0.1864 & 0.5981 & 0.8338 & 0.8933 & \\
\hline & Fill in Tax Return & 0.5349 & & & & \\
\hline & Report the Tax & 0.5755 & & & & \\
\hline & Paying Taxes & 0.6848 & & & & \\
\hline
\end{tabular}

(Source: Data Processed By XLSTAT Software)

From information over the consequences of information preparing from surveys utilizing XLSTAT programming demonstrate the marker in united legitimacy estimation of every factor has a factor stacking more than 0.50 methods the announcement in the poll substantial, the higher the factor stacking the higher the legitimacy. From table 1 above demonstrate that the worth AVE and commonness from by and large factor more noteworthy than 0.5 and met the criteria discriminant legitimacy. With the goal that it very well may be expressed that the inquiry things are substantial in estimating the variable. For reliability test utilizing Cronbach Alpha and D.G. rho (PCA), from table 1 over the benefit of utilizing Cronbach Alpha and D.G. rho (PCA) show that development of every factor has a Cronbach Alpha more than 0.70 methods the announcement in the survey solid and can speak to the factors in this examination. The GoF estimation of 0.9401 implies that the decent variety of information can be clarified by the model or as it were the data contained in the information is $94.01 \%$ can be clarified by the model. While staying $5.99 \%$ is clarified by different factors outside the model utilized in this examination.

Table 2. Result of Hypothesis Testing

\begin{tabular}{|c|c|c|c|c|c|c|c|c|c|}
\hline Hypothesis & $\begin{array}{c}\text { Path } \\
\text { Coefficient }\end{array}$ & t-test & t-table & $\operatorname{Pr}>|t|$ & $\begin{array}{l}\text { Variable } \\
\text { Exogenous }\end{array}$ & $\begin{array}{c}\text { Variable } \\
\text { Endogenous }\end{array}$ & $\begin{array}{c}\text { Intervening } \\
\text { Variable }\end{array}$ & Impact & Result \\
\hline $\mathrm{H}_{1}$ & 0.0672 & 0.4998 & & 0.6185 & & & & & Not Accepted \\
\hline $\mathrm{H}_{2}$ & 0.5847 & 6.5656 & & 0.0000 & & & & & Accepted \\
\hline $\mathrm{H}_{3}$ & & 0.7721 & & 0.4423 & $\begin{array}{l}\text { Perception of } \\
\text { Using e- } \\
\text { Filling }\end{array}$ & $\begin{array}{l}\text { Compliance } \\
\text { of Tax }\end{array}$ & $\begin{array}{l}\text { Knowledge } \\
\text { of Tax }\end{array}$ & 0.0698 & Not Accepted \\
\hline
\end{tabular}

(Source: Data Processed By XLSTAT Software) 
The aftereffects of testing speculation in this examination can be found in table 2 above, $\mathrm{H}_{1}$ not accepted view of utilizing e-Filling doesn't affect legitimately to assess the tax compliance of disability citizens in Bandung, West Java. $\mathrm{H}_{2}$ acknowledged methods impression of utilizing e-Filling significantly enhance tax knowledge or information of handicap citizens on Bandung, West Java, oppositely $\mathrm{H}_{3}$ not acknowledged methods the duty learning of incapacity citizens can't directing the impact of utilizing e-Filling to assess tax compliance of inability citizens.

\section{Discussion}

Result on this research not supported a state by Mardiasmo (1997: 104) that the reason people are less enthusiastic about paying taxes (less tax compliance) is because of a lack of knowledge about taxes. Theoretically, to foster a positive attitude about something that must originate from the existence of knowledge about it. Taxpayer compliance can be further grown if tax management is also disciplined, and the tax apparatus works honestly. in this research the sample (disability taxpayers) knowledge enchancement cannot impact the tax compliance. Sriartati's research (2000) inline with result of this research that the taxation system adopted by an area including simplification of tax administration greatly affected the level of public awareness in tax knowledge.

\section{Conclusion}

Taking a gander at the aftereffects of poll preparing, it is expressed that the impression of the utilization of e-filling can expand citizen tax knowledge- learning of SMEs with incapacities with the best discernment seen from the speed measurement in utilizing e-filling contrasted with utilizing the expense framework physically where the handicaps must go to the assessment office to fill the government form and report it, yet then again this expanded duty information isn't joined by tax compliance from inabilities and tax knowledge can't direct the impact of e-filling on the tax compliance of people with incapacities in the city of Bandung. There's a more important thing to gain more tax compliance in disability taxpayers that e-filling services must contain disability-friendly mode, moreover, there's be a waste of money if disability cannot understand what information contained in the website of e-Filling moreover for the blind taxpayers. The government needs to improve the mode disability -friendly so it can be work effectively on disability taxpayers.

This examination was just directed on a network of SME's inability in West Java domiciled in Bandung. In future research more extensive research on the inability of SMEs domiciled in other cities. To guarantee outside legitimacy, more extensive examples are required all through the differing topographies required in future research. The factors utilized in this investigation are restricted. For future research can be added to different factors not analyzed in this investigation which additionally have an impact on tax compliance consistence. 


\section{References}

H Rosdiana. Pengantar Ilmu Pajak, Kebijakan dan Implementasi di Indonesia, KnE Social Sciences 3 (10), 609-620, 2018.

Herdjati, Tyassih. 1996. Pengaruh Tingkat Pendidikan Serta Pengetahuan Pajak Wajib Pajak terhadap Kepatuhan WP dalam Membayar PBB di Kotamadya Dati II Semarang. Semarang: Perpustakaan FE UNDIP.

Ismail, et al. (2020). The Community Perceptions of Poverty in Gampong Ayon, Seulimeum Sub-district, Aceh Besar Regency (Research Results on March 2017). Budapest International Research and Critics Institute-Journal (BIRCI-Journal). P. 270-275.

Kesit Bambang Prakosa, Analisis Pengaruh Dana Alokasi umum (DAU) dan Pendapatan Asli Daerah. JAAI volume 8 no. 2, Desember 2004.

Mardiasmo, 1997. Perpajakan, Yogyakarta: Penerbit Andi.

Mardiasmo, 2001. Perpajakan Edisi Revisi Tahun 2002 Revisi , Andi Offset,. Yogyakarta.

Marpaung, A. (2020). Zakat Regulation as a Reduction of Income Tax in Indonesia. Budapest International Research and Critics Institute-Journal (BIRCI-Journal). P. 2109-2116.

Misbach, Moch. Lutfie. 1997. Faktor yang Mempengaruhi Keberhasilan Penerimaan PBB di Surabaya. Surabaya: Tesis Universitas Airlangga.

Malhotra, Naresh K. 2006. Marketing Research An Applied Orientation. Prestice Hall, United State of America.

Nazir, M. 2010. Metode Penelitian. Ghalia Indonesia, Bogor.

Nurmantu, Safri. 1994. Dasar_Dasar Perpajakan. Jakarta: Ind Hill-Co.

Setyaningsih, R., \& Gutama, T. A. (2016). Pengembangan Kemandirian bagi Kaum Difabel (Studi Kasus pada Peran Paguyuban Sehati dalam Upaya Pengembangan Kemandirian bagi Kaum Difabel di Kabupaten Sukoharjo). DILEMA, 31(1), 42-52.

Siti Resmi, Perpajakan dalam Teori dan Praktek, Salemba Empat, edisi 8, 2011

Siregar, R., et al. (2019). The Effect of Corporate Taxpayer Compliance, the Increase of Corporate Taxpayers' Number and Tax Audits on Income Tax Receipts of Article 25 with Taxation Sanctions as a Moderating Variable in KPP Pratama Medan Petisah. Budapest International Research and Critics Institute-Journal (BIRCI-Journal). P. 385-400.

Sriartati, Rara. 2000. Studi Tentang Sistem Administrasi Perpajakan dan Kesadaran Masyarakat dalam Membayar PBB di Kelurahan Bandarharjo Kecamatan Semarang Utara. Semarang: Tesis Undip.

Supramono dan Damayanti, Theresia Woro. 2005. Perpajakan Indonesia: Mekanisme dan Perhitungan. Yogyakarta: Andi.

Sugiyono. 2013. Metode Penelitian Kuantitatif Kualitatif dan R \& D. Bandung : Alfabeta.

Wahyuni, Rezky\&Kirmizi Ritonga, Rusli. Pengaruh Persepsi Kegunaan, Kemudahan, Keamanan Dan Kerahasiaan, Dan Kecepatan Terhadap Intensitas Perilaku Dalam Penggunaan E-Filing (Studi Pada Wajib Pajak Orang Pribadi Di Kantor Pelayanan Pajak Pratama Pekanbaru Senapelan). Jurnal Online Mahasiswa.Vol.2 No.1 (2015). 